\title{
PENGAJARAN KITAB-KITAB FIQIH DI PESANTREN
}

\author{
Oleh Husen Hasan Basri*)
}

\section{Abstract}

In addition to clerics and values, yellow books are essential elements of an Islamic boarding school. Yellow Books are Islamic boarding school instructional materials that have been used for a long time. One area of yellow book that has been long taught is jurisprudence (fiqh) field. Teaching of fiqh books starts from the low level books, such as Safinahan-Najah to the high level books, such as Al-Muhadzdzab. Teaching methods used were Bandongan and Sorogan methods. In line with diversified development of forms and types of education in Islamic boarding schools, such as formal education (madrassas and schools) and vocational education, it is expected that teaching of yellow books, including books of fiqh, was changing, either books taught, teaching methods used, number of meetings in teaching, and teaching level. Through a survey of 951 schools in 15 provinces of 72 books of figh chosen by the researchers, there were 5 books of 72 books of fiqh included in a group of the most widely taught books of figh, namely: Taqrib, Safinah an-Najah, Fath al-Mu'in, Fath al-Qarib, and Sullam at-Taufiq. Besides Fath al-Mu'in, these books are elementary books of fiqh.

Keywords: Teaching of Yellow Books, Fiqh Books, Islamic Boarding School

\section{Abstrak}

Selain Kyai dan tata nilai, kitab kuning merupakan unsur pokok dari sebuah pondok pesantren. Kitab kuning adalah bahan ajar pesantren yang sudah lama digunakan. Salah satu bidang kitab kuning yang sudah lama diajarkan adalah bidang fiqih. Pengajaran kitab-kitab fiqih dimulai dari kitab tingkat rendah seperti kitab Safinah an-Najah sampai kitab tinggi seperti kitab al-Muhadzdzab. Metode pengajarannya menggunakan metode bandongan dan sorogan. Seiring dengan munculnya diversifikasipengembanganbentukdanjenis-jenisPendidikandipesantrensepertiPendidikanformal (madrasah dan sekolah) dan Pendidikan keterampilan, diduga pengajaran kitab kuning, termasuk kitab-kitab fiqih, mengalami perubahan pengajaran kitab, baik kitab-kitab yang diajarkan, metode pengajaran yang digunakan, jumlah pertemuan dalam pengajaran, dan tingkat pengajaran. Melalui survei pada 951 pesantren di 15 propinsi terhadap 72 kitab fiqih hasil pilihan peneliti, terdapat 5 kitab dari 72 kitab fiqih yang termasuk kelompok kitab fiqih yang banyak diajarkan, yaitu: Taqrib, Safinah an-Najah, Fath al-Mu'in, Fath al-Qarib, dan Sullam at-Taufiq. Kecuali, Fath al-Mu'in, kitab-kitab tersebut merupakan kitab-kitab fiqih elementer.

Kata kunci: Pengajaran Kitab Kuning, Kitab-Kitab Fiqih, Pesantren

*) Peneliti Muda Pada Puslitbang Pendidikan Agama dan Keagamaan. hhasanbasri@yahoo.com, 081319157303

Naskah diterima 10 Januari 2012. Revisi pertama, 2 Februari 2012, revisi kedua 27 Februari 2012, revisi ketiga 2 April 2012 


\section{PENDAHULUAN}

\section{Latar Belakang}

Kitab kuning merupakan salah satu elemen penting dari sebuah pesantren. Kitab kuning telah menjadi bahan ajar pesantren dalam waktu yang lama sehingga kitab kuning memiliki posisi dan peran yang signifikan di pesantren. Walaupun telah berkembang Pendidikan Islam formal, tidak berlebihan kalau kekuatan Pendidikan Islam pada masa lalu masih berada pada sistem pesantren. Hal ini sebagian disebabkan oleh suksesnya lembaga tersebut menghasilkan sejumlah ulama yang berkualitas tinggi. Kesuksesan ini tidak terlepas dari faktor kealiman kyai, pengajaran kitab kuning, dan sistem nilai. Kalaupun dikenal sistem pemberian ijazah, kompetensi lulusan santrinya diukur berdasarkan pada sejauhmana seorang santri telah menyelesaikan pelajarannya dengan baik tentang suatu kitab tertentu sehingga si santri tersebut dianggap menguasai dan mengajarkannya kepada orang lain.

Kitab Kuning di pesantren lebih didominasi oleh teks-teks keilmuan yang lebih kental dengan nuansa fiqih ketimbang bidang lain seperti tafsir, tasawwuf, teologi, usul fiqih dan lain-lain. Fiqih adalah primadona kaum santri dan salah satu disiplin keilmuan Islam yang paling diminati. Kitab-kitab fiqih yang menjadi bahan kajian di pesantren lebih banyak berasal dari aliran Syafi'iyah khususnya kitab-kitab yang ditulis pada abad keenam sampai abad kesepuluh Hijriah. ${ }^{1}$

Kitab-kitab fiqih di pesantren dipelajari melalui metode bandongan dan sorogan. Selain kedua metode tersebut, sejalan dengan usaha kontekstualisasi kajian kitab

1 Imam Nakhai, Peranan Kitab-Kitab Fiqih dalam Menciptakan Budaya Damai dalam Konteks Negara Bangsa:Telaah terhadap Budaya Damai dalam Kitab-kitab Kuning Otoritatif di Dunia Pesantren, tidak diterbitkan, 2011. kuning, di lingkungan pesantren sejak tahun 1990-an telah berkembang metode diskusi. Metode ini lebih sering digunakan di tingkat kiai-ulama atau pengasuh pesantren untuk, antara lain, membahas isu-isu kontemporer dengan bahan-bahan pemikiran yang bersumber dari kitab kuning. ${ }^{2}$

Tradisi pengajaran kitab kuning itu berorientasi pada: pertama, kitab kuning diajarkan secara berjenjang dari mulai kitab elementer sampai kitab tingkat tinggi. Kedua, kitab kuning elementer banyak diajarkan, dan kitab kuning tinggi menjadi rujukan kaum santri tingkat tinggi atau ustadz atau kyai dalam forum pengkajian kitab seperti bahtsul masail, dan ketiga, pengajaran kitab kuning di pesantren tidak variatif (variasinya yang rendah). Kitab kuning tidak perlu diajarkan semua, kyai pesantren cukup mengajarkan beberapa kitab yang perlu dikuasai, setelah menguasai santri dibebaskan untuk mempelajari kitab lain secara mandiri.

Kondisi saat ini, menurut sebagian praktisi dan pemerhati pesantren, tradisi pengajaran kitab kuning termasuk kitabkitab fiqih, diduga mengalami perubahan pengajaran kitab, baik kitab-kitab yang diajarkan, metode pengajaran yang digunakan, jumlah pertemuan dalam pengajaran, maupun tingkat pengajaran seiring dengan munculnya diversifikasi pengembangan bentuk dan jenis-jenis Pendidikan di pesantren seperti Pendidikan formal (madrasah dan sekolah) dan Pendidikan keterampilan serta munculnya sumber belajar baru yang berasal dari perkembangan teknologi informasi.

Memang saat membuka Pendidikan formal, pesantren tetap mengajarkan kitab kuning. Tetapi, apakah dengan waktu yang terbagi dengan materi pelajaran pada

2 Lihat Affandi Mochtar, "Tradisi Kitab Kuning: Sebuah Observasi Umum", dalam Marzuki Wahid, dkk (penyunting), Pesantren Masa Depan: Wacana Pemberdayaan dan Transformasi Pesantren, 1999, Bandung: Pustaka Hidayah, hal. 224 
Pendidikan formal akan cukup untuk pengajaran kitab kuning. Mungkin untuk pesantren-pesantren yang tetap fokus pada pengajaran kitab kuning (pesantren salafiyah murni atau salafiyah tradisional) tidak ada masalah, barangkali untuk pesantrenpesantren yang membuka Pendidikan formal muncul masalah dalam pembagian waktu antara mengikuti aturan-aturan formal (standar nasional Pendidikan) dengan pengajaran kitab kuning.

Saat ini banyak pesantren yang mengikuti Pendidikan formal tetapi pesantrenpesantren tersebut tetap mengajarkan kitab kuning. Tahun 2009-2010, terdapat 24.206 pesantren dengan 3.647 .719 santri. Dari jumlah tersebut, 13.477 (56\%) buah adalah pesantren salafiyah dimana kitab kuning menjadi fokus pengajarannya, dan 7.564 (31\%) buah adalah pesantren Kombinasi dimana selain belajar kitab kuning juga menyelenggarakan Pendidikan formal. ${ }^{3}$ Jika pesantren-pesantren tersebut-setidaknya $87 \%$ pesantren-mengajarkan kitab kuning, apakah dalam pengajaran kitab kuning itu masih menggunakan tradisi pengajaran kitab kuning yang sudah lama diperaktekkan atau menerapkan tradisi lain dalam pengajaran kitab kuning. Maka dalam konteks itulah penelitian tentang pengajaran kitab kunig di pesantren dilakukan.

\section{Pertanyaan Penelitian}

1. Kitab-kitab fiqih apa yang banyak diajarkan di pesantren?

2. Apa metode yang digunakan dalam pengajaran kitab-kitab fiqih?

3. Berapa jumlah pertemuan pengajaran kitab-kitab fiqih?

4. Kitab-kitab fiqih itu diajarkan pada tingkat apa?

3 EMIS, Statistik Pendidikan Diniyah dan Pondok Pesantren, Tahun ajaran 2009-2010.
Tujuan Penelitian

Penelitian ini bertujuan untuk mendeskripsikan:

1. Kitab-kitab fiqih yang banyak diajarkan di pesantren

2. Metode pengajaran kitab-kitab fiqih yang digunakan

3. Jumlah pertemuan pengajaran kitabkitab fiqih

4. Tingkat pengajaran kitab-kitab fiqih

\section{Manfaat Pe nelitian}

Melalui penelitian ini diharapkan dapat tergambarkannya peta kitab-kitab fiqih yang banyak diajarkan di pesantren, metode dan jumlah pertemuan pengajaran kitabkitab fiqih, dan tingkatan pengajaran kitabkitab fiqih (ula, wustha, 'ulya, dan Ma'had 'Aly). Selanjutnya data ini dapat menjadi dasar pembuatan pedoman standarisasi penyetaraan Pendidikan pesantren berbasis kitab kuning, serta dapat melengkapi dan memperkuat buku Pedoman Standarisasi Kurikulum Pendidikan Pesantren yang telah dibuat oleh Direktorat Pendidikan Diniyah dan Pondok Pesantren.

\section{Metode Penelitian}

Metode pengumpulan data menggunakan metode kuantitatif dengan jenis survei. Jenis survei ini dipilih karena dianggap tepat untuk mendapatkan peta kitab-kitab fiqih yang banyak diajarkan, metode pengajaran, jumlah pertemuan, dan tingkat pengajaran kitab-kitab fiqih. Survei dilakukan pada bulan Mei-Juni 2011.

Target populasi yang menjadi sasaran penelitian seluruh pesantren di 15 propinsi di Indonesia, yaitu: Jabar, Jatim, Jateng, Banten, DIY, Aceh, Sumut, Sumbar, Sumsel, Jambi, Lampung, Kalsel, Kalbar, NTB, dan Sulsel. Secara nasional, di lima belas propinsi ini mencakup 23.065 pesantren atau (95,3\%) dari 24.206 pesantren. Kelima 
belas propinsi tersebut dipilih karena memiliki jumlah pesantren yang banyak. Untuk memenuhi Margin Error +/- 3,1\% ditetapkan besaran sampel survei sekitar 996 pesantren. Kerangka sampel menggunakan nama-nama pondok pesantren yang terdaftar pada EMIS tahun 2008-2009.

Sebelum penarikan pesantren secara random, ditetapkan terlebih dahulu kategori pesantren salafiyah, pesantren kombinasi dan pesantren ashriyah untuk masing-masing propinsi. Langkah selanjutnya adalah pada masing-masing propinsi dipilih kabupaten-kabupaten yang mewakili kabupaten yang memiliki kategori pesantren salafiyah terbanyak, sedang, dan rendah; kabupaten-kabupaten yang mewakili kabupaten yang memiliki kategori pesantren ashriyah terbanyak, sedang dan rendah; juga kabupatenkabupaten yang mewakili kabupaten yang memiliki kategori pesantren kombinasi terbanyak, sedang dan rendah.

Setelah itu mendaftar pesantren di masing-masing kabupaten terpilih. Kemudian secara random dipilih pesantrenpesantren di masing-masing kabupaten terpilih sesuai dengan jumlah sampel yang telah ditentukan berdasarkan proporsi populasi masing-masing kabupaten yang mewakili. Berdasarkan jumlah sampel 996 pesantren, sebanyak 951 sampel akhir pesantren yang berasal dari 89 kabupaten dan kota. 951 pesantren itu terdiri dari 530 pesantren salafiyah, 300 pesantren kombinasi, dan 121 pesantren 'ashriyah.

Sumber data survei ini adalah pimpinan dan santri pesantren. Untuk mengambil sumber data atau responden survei dilakukan metode berikut. Dari 951 pesantren yang terjaring, didapat 951 pimpinan dan 2146 santri sebagai sumber data (responden). Untuk kyai ditanyakan tentang kitab-kitab fiqih apa yang banyak diajarkan dan tingkat pengajaran kitab-kitab fiqih. Sementara untuk santri ditanyakan tentang metode dan jumlah pertemuan pengajaran kitabkitab fiqih.
Data yang terkumpul dilakukan validasi dan coding serta dilakukan proses entry. Selanjutnya, data ditabulasi dan disajikan dalam bentuk tabel dan grafik. Data yang telah terkategorisasi selanjutnya dianalisa dengan statistik deskrptif untuk mendapatkan hasil temuan yang diajukan sebelumnya. Berdasarkan masukan data dari hasil entry, tabulasi, uji statistik, selanjutnya paparan temuan disampaikan secara deskriptif.

\section{KERANGKA KONSEP}

Kitab-Kitab Fiqih

Pendefinisian istilah kitab kuning beragam. Pendefinisian kitab kuning itu ada yang dibatasi dengan tahun karangan, mazhab teologi, istilah mu'tabarah, dan sebagainya. Selain istilah kitab kuning, untuk menyebut jenis kitab yang sama beredar istilah 'kitab klasik'(al-kutub alqadimah), 'kitab gundul', dan 'kitab kuno'. Pengertian yang umum beredar di kalangan pemerhati masalah pesantren adalah bahwa kitab kuning selalu dipandang sebagai kitab-kitab keagamaan berbahasa Arab, atau berhuruf Arab, sebagai produk pemikiran ulama-ulama masa lampau (assalaf) yang ditulis dengan format khas pramodern, sebelum abad ke-17-an M. Dalam Rumusan yang lebih rinci, definisi kitab kuning adalah kitab-kitab yang: a) ditulis oleh ulama-ulama 'asing' tetapi secara turun-temurun menjadi rujukan yang dipedomani oleh para ulama Indonesia, b) ditulis oleh ulama Indonesia sebagai karya tulis yang 'independen', dan c) ditulis oleh ulama Indonesia sebagai komentar atau terjemahan atas kitab karya ulama 'asing'4. Menurut Azyumardi Azra, kitab kuning adalah kitab-kitab keagamaan berbahasa Arab, Melayu atau Jawa atau bahasa-bahasa

4 Affandi Mochtar, "Tradisi Kitab Kuning: Sebuah Observasi Umum", dalam Marzuki Wahid, dkk (penyunting), Pesantren Masa Depan: Wacana Pemberdayaan dan Transformasi Pesantren, 1999, Bandung: Pustaka Hidayah, hal. 222 
lokal lain di Indonesia dengan menggunakan aksara Arab, yang selain ditulis oleh ulama di Timur Tengah, juga ditulis oleh ulama Indonesia sendiri. ${ }^{5}$

Studi Van den Berg (1886) merupakan survei paling terperinci mengenai kitabkitab yang umum dipelajari di pesantren Jawa. Van den Berg menyebutkan lima puluh judul kitab. Selanjutnya Bruinessen mencantumkan ada sekitar 900 buku (kitab) yang digunakan di pesantren (buku teks) dan kemungkinan buku-buku tersebut masih dicetak dan digunakan sampai saat ini. Menurut Bruinessen, bidang fiqih merupakan satu disiplin ilmu yang paling banyak diajarkan di pesantren. Karena itu dari sekitar 900 judul kitab kuning yang beredar di pesantren, 20\% (sekitar 180 kitab) yang bersubstansikan fiqih.

Menurut Bruinessen, karya-karya fikih yang paling populer adalah Taqrib dan syarahnya Fath Al-Qarib. Hampir tidak ada pesantren yang tidak menggunakan paling tidak salah satu dari kedua kitab ini. Lebih lanjut Bruinessen mengatakan ada beberapa "keluarga" kitab fikih Syafii dan hubungan antara anggota keluarga ini, yaitu Muharrar karangan Rafi'i (w.625 H/1226 M), Taqrib (atau Mukhtashar) oleh Abu Syuja' Al-Isfahani (w.593 H/1197 M)), dan Qurrah Al-'Ain karangan Malibari (w.kira-kira 975 H/1567 M). Muharrarnya Imam Rafi'i pertama-tama disingkat oleh Abu Zakariya Yahya bin Syaraf Al-Nawawi menjadi Minhaj At-Thalibin. Karya ini telah melahirkan banyak syarah, diantaranya lima yang paling penting yaitu: Kanz AlRaghibin (Muhalli), Manhaj Al-Thullab (Zakariya Al-Anshari), Tuhfah Al-Muhtaj (Ibn Hajar Al-Haitami), Nihayatul Muhtaj (Samsudin Ramli), dan Mughni Al-Muhtaj (Sayrbini). Dari kitab Kanz Al-Raghibin lahir hasyiyah Qalyubi dan 'Umaira. Dan Fath

5 Azra, Azyumardi. "Kitab Kuning: Tradisi dan Epistemologi Keilmuan Islam di Indonesia", Azyumardi AZra, Pendidikn Islam: Tradisi dan Modernisasi Menuju Milenium Baru", 2002, Jakarta, Logos, hal 111
Al-Wahab sebuah syarah karya Zakariya Anshari atas karangan sendiri Manhaj AlTullab. Mir'at Al-Tullab karya Abdurrauf Al-Singkili merupakan terjemahan Fath AlWahhab dalam bahasa Melayu.

Dari Taqrib lahir syarah-syarahnya seperti Fath Al-Qarib (Ibn Qasim), Kifayatul Al-Akhyar (Dimasyqi), dan Iqna' (Khatib Syarbini). Dari Qurrah Al-ain disyarahi oleh Malibari sendiri menjadi Fath Al-Mu'in. Dan Nawawi Banten menulis syarah Qurrah Al-'Ain yakni Nihayah Al-Zain. Hasyiyah atas Fath Al-Mu'in adalah I'anah al-Thalibin karya Sayid Bakri bin Muhammad Syatha Al-Dimyati dan Tarsyih Al-Mustafidin karya Alwi Al-Saqqaf.6

Garis lain kitab-kitab fiqih yaitu kitab al-Muqaddimat al-Hadhramiyyah karya Abdullah bin Abdul Karim Bafadhal. Dari garis ini lahir tiga kitab kuning baru, yaitu: Minhaj al-Qawwim, yang pada abad ke-18 melahirkan kitab Hawashi al-Madaniyah. Dua kitab komentar lagi atas kitab al-Muqadimah adalah, pertama, sebuah kitab komentar yang ditulis dalam bahasa Arab oleh ulama Indonesia, Mahfudz bin Abdullah at-Tarmisi (w.1338 H/1919 M), dan kedua, kitab Busyr al-Karim bi Syarah Masail atTa'lim 'ala Muqadimah al-Hadramiyah (karya Sa'id bin M. Bahsin). Selain kitab-kitab fiqih yang mempunyai hubungan dengan empat garis asal-muasal di atas, masih banyak kitab-kitab fiqih yang terkenal di lingkungan pesantren. Untuk menyebut beberapa contoh, diantaranya adalah kitab Sullam at-Taufiq (Abdullah bin Husayn bin Thahir Ba'alawi, w.1271/1855M), kitab Safinah an-Najah (Salim bin Abdullah bin Sumayr, tinggal di Jakarta pertengahan abad ke $19 \mathrm{M}$ ), kitab Muhadzdzab karangan Ibrahim asy-Syirazi al-Fayruzabadi (w.467 H/1083 M), kitab Bughyah al-Mustarsyidin (sebuah koleksi fatwa ulama abad ke19/20 M, karya Abdurahman bin Husayn Ba'alawi), dan kitab 'Uqud al-Lujayn fi

6 Bruinessen, Martin Van.. Kitab Kuning, Pesantren dan Tarekat: Tradisi-Tradisi Islam di Indonesia, 1999, Bandung, Mizan, hal. 131-132. 
Huquq az-Zawjayn karya Syaikh Nawawi al-Bantani.

Penelitian Mastuhu tahun 1994 sekitar kitab yang digunakan pada 6 pesantren terkemuka di Jawa (Guluk-guluk, Sukorejo, Blok Agung, Tebuireng, Paciran dan Gontor) terdapat sekitar 7 bidang kajian agama Islam (tauhid, tafsir, hadis, fikih, usul fikih, tasawuf, nahu/ saraf/balagah, mantik dan ahlak) dan menggunakan 112 macam kitab. Kitab-kitab fiqih yang dikaji pada 6 pesantren itu yaitu: pertama, pesantren Gulukguluk; Minhaj Al-'Abidin, Fath Al-Wahhab, Fath Al-Mu'in, Fath Al-Qarib, Sullam AtTaufiq, Fath Al-Jawad, dan Minhaj Al-Qawim. Kedua, pesantren Sukorejo; Safinat AnNajah, Sullam At-Taufiq, Fath Al-Qarib, Fath Al-Mu'in, Fath Al-Wahhab, Minhaj Al-Abidin, Minhaj Al-Qawim, Kifayat Al-Akhyar, dan AlIqna fi Al-Fadli Abi Syuja'. Ketiga, pesantren Blok Agung; Al-lqna fi Al-Fadli Abi Syuja', Fath Al-Wahhab, Kasyifat As-Saja, Fath AlMu'in, Sullam As-Safinah, Kifayat Al-Akhyar, Fath Al-Qarib, Bahjat Al-Wasail, Bugyat AlMustarsyidin, Minhaj Al-Qawim, Sullam AtTaufiq, Al-Asybah wannadhoir, dan Sullam Al-Munajat. Keempat, pesantren Tebuireng; Mabadi' Al-Fiqh, Taqrib, Fathul Mu'in, Fath Al-Wahhab, Al-Muhadzdzab, Al-Asybah wannadhoir, Mizan Al-Kubra, dan Minhaj Al'Abidin. Kelima, pesantren Paciran; Bidayat Al-Mujtahid. Keenam, pesantren Gontor; Pengantar Fiqih, Al-Figh Al-Wadih 1,2,3, dan Bidayat Al-Mujtahid.?

Dalam penelitian ini kitab-kitab fiqih adalah kitab-kitab keagamaan berbahasa Arab, Melayu atau Jawa atau bahasa-bahasa lokal lain di Indonesia dengan menggunakan aksara Arab, yang selain ditulis oleh ulama di Timur Tengah, juga ditulis oleh ulama Indonesia sendiri yang berisikan keilmuan fiqih.

Daftar nama-nama kitab-kitab fiqih yang dijadikan bahan dasar pene-

7 Mastuhu. Dinamika sistem Pendidikan Pesantren, 1994, INIS, Jakarta, hal. 170-173 litian berasal dari (a) studi Martin Van Bruinessen, (b) Appendix C Daftar Kitabkitab dalam Sudjoko Prasodjo, dkk, (c) Lampiran 2: Daftar Kitab yang Dikaji dalam Pesantren dalam Mastuhu, (d) Studi Puslitbang Lektur Keagamaan tahun 2006, (e) Kitab-kitab standar Ma'had Aly, Kitab Standar Pokok Jurusan Figh dan Ushul Fiqh Ma'had Aly, dan Kutub Al-Maraji' AlMuqarrarah Ma'had Aly, (f) Acuan kitabkitab dan/atau yang sederajat sesuai Surat edaran Direktorat Jenderal Kelembagaan Agama Islam, Nomor: Dj.II.II/V/PP.007/ AZ/28/04 tanggal 9 Januari 2004, pada tahun 2008 Direktorat Jenderal Pendidikan Islam Departemen Agama RI menetapkan kebijakan terhadap lulusan pondok pesantren dan Pendidikan diniyah yang meliputi pengakuan kesetaraan lulusan dan legalisasi ijazah/syahadah pondok pesantren dan Pendidikan diniyah. Kitabkitab fiqih yang dijadikan sasaran sebagai pilihan peneliti sebanyak 72 kitab.

\section{Pengajaran Kitab-Kitab Fiqih}

Pengajaran kitab kuning adalah proses belajar mengajar yang menggunakan kitab kuning sebagai sumber belajarnya. Dalam kegiatan belajar mengajar kitab kuning melibatkan beberapa komponen, yakni santri yang belajar, kyai atau ustadz yang mengajar, isi pelajaran, metode, sistem pengajaran, bahasa pengantar, dan evaluasi.

Hampir setiap pesantren mengajarkan kombinasi kitab yang berbeda-beda, dan banyak kyai terkenal sebagai spesialis kitab tertentu. Pesantren berbeda dengan madrasah dalam hal, disamping beberapa hal lainnya, tidak adanya keseragaman dalam kurikulum. 8 Banyak kyai yang mengkhususkan diri menekuni salah satu cabang ilmu, atau bahkan salah satu kitab tertentu. Karena alasan ini pula, banyak

8 Steenbrink, Karel A., Pesantren, Madrasah, Sekolah: Pendidikan Islam dalam Kurun Moderen, 1994, Jakarta, LP3ES. hal 166-167. 
para santri yang berpindah dari satu pesantren ke pesantren lainnya untuk belajar sejumlah kitab tertentu secara menyeluruh. Tidak ada satu pun pesantren yang memberikan kurikulum yang mewakili semua.

Jenis Pendidikan 'pesantren' bersifat non formal hanya mempelajari agama yang bersumber pada kitab-kitab klasik (kitab kuning) meliputi bidang-bidang studi: Tauhid, Tafsir, Hadits, Fiqih, Ushul Fiqih, Tasawuf, Bahasa Arab (Nahwu, Sharaf, Balaghah dan Tajwid), Mantiq, dan Akhlaq. Kurikulum dalam jenis Pendidikan 'pesantren' berdasarkan tingkat kemudahan dan kompleksitas ilmu atau masalah yang dibahas dalam kitab, jadi ada tingkat awal, tingkat menengah dan tindak lanjut, misalnya pesantren Blok Agung berkeyakinan bahwa sebelum seorang anak belajar lebih lanjut, minimal mereka harus mempelajari kitab-kitab awal keagamaan fiqih-sufistik. 9

Diantara kitab kuning yang diajarkan secara intensif berasal dari "gen". "Gen" atau matan (matn) ini kemudian dikembangkan menjadi komentar (syarh), catatan pinggir (hasyiyah), bahkan adakalanya muncul dalam bentuk ringkasan (mukhtashar) dan syair (nazham). Kitab kuning dalam pesantren berjalan dalam siklus yang tetap: mengembang, menyempit, berputar, dan berulang. Beberapa contoh dapat disebutkan, misalnya, dalam fikih: AtTaqrib, Fathu al-Qarib karya al-Bajuri, Qurrah al-'Ayn, Fath al-Mu'in, I'anatuh athTahalibin atau Nihayah az-Zayn. Contoh dalam bidang nahwu adalah: Al-Ajurumiyah, al-Asymawi, ad-Dahlan, al-Khalid, al-Kafrawi, al-Mutammimah, al-'Imrithi hingga Alfiyah Ibn Malik dan Ibn 'Aqil. Sebuah cabang ilmu boleh jadi dikupas dan diringkas dalam puluhan kitab kuning. Semuanya diajarkan

${ }_{9}$ Mastuhu, op. cit., 142 berulang-ulang dan bertahun-tahun selama mengikuti Pendidikan di pesantren. 10

Selama kurun waktu yang panjang, pesantren telah memperkenalkan dan menerapkan beberapa metode: bandongan, sorogan, hafalan, dan diskusi.11 Semua metode ini dilakukan dalam sistem halaqah ${ }^{12}$ maupun klasikal (madrasah). Metode bandongan adalah cara penyampaian kitab kuning di mana seorang guru atau ustadz membacakan dan menjelaskan isi kitab kuning, sementara santri, murid, atau siswa mendengarkan, memberi makna, dan menerima. Dalam metode ini, guru berperan aktif, sementara murid bersikap pasif. Adapun metode sorogan adalah murid membaca dan guru mendengarkan sambil memberi catatan, komentar, atau bimbingan bila diperlukan. Catatan itu bisa berupa syakl atau makna mufrodat atau penjelasan. Metode bandongan atau sorogan memiliki ciri penekanan yang sangat kuat pada pemahaman tekstual atau literal. Metode hafalan adalah belajar sendiri secara individual dengan jalan menghapal. Metode ini telah menjadi ciri dan cap yang melekat pada sistem Pendidikan tradisional, termasuk pesantren. Dalam pengajaran kitab kuning digunakan metode diskusi (munazharah). Metode ini adalah penyajian bahan pelajaran dengan cara murid atau santri membahasnya bersama-sama melalui tukar pendapat tentang suatu topik atau masalah tertentu

10 Husen Muhammad, "Kontekstualisasi Kitab Kuning: Tradisi Kajian dan Metode", dalam Marzuki Wahid, dkk (penyunting), Pesantren Masa Depan: Wacana Pengembangan dan Transformasi Pesantren, 1999, Bandung, Pustaka Hidayah, hal. 270-271

11 Mastuhu mengistilahkan dengan lalaran. Metode lalaran adalah belajar sendiri secara individual dengan jalan menghapal, biasanya dilakukan di mana saja seperti di dekat makam, serambi Mesjid, serambi kamar dan sebagainya. Lihat Mastuhu, op.cit., hal. 144

12 Mastuhu dan Affandi Mochtar mengartikan istilah halaqah bukan sebagai sistem tetapi sebagai metode pegajaran. Keduanya mengartikan istilah halaqah yaitu metode seminar atau diskusi. Mochtar, op.cit., hal.223 dan Mastuhu, op.cit., hal. 144. 
yang ada dalam kitab kuning. Di beberapa pesantren, mengaji kitab kuning dengan metode munazharah berjalan cukup baik dan bahkan mampu memacu para santri untuk melakukan telaah (muthala'ah) atas kitab yang besar-besar. Di masa lalu, mengaji dengan metode munazharah menjadi sebuah tradisi para ulama. ${ }^{13}$

Selain metode-metode di atas, pengajaran kitab kuning dapat dilakukan melalui metode penulisan ilmiah, sekurang-kurangnya dengan menulis resume atau ikhtisar atas topik yang ada dalam kitab kuning, dan metode evaluasi dalam bentuk penilaian atas tugas, kewajiban dan pekerjaan. Cara ini dilakukan setelah kajian kitab kuning selesai dibacakan atau disampaikan. Di masa lalu, cara ini disebut imtihan, yakni suatu pengujian santri melalui munaqasyah oleh para guru atau kyai di hadapan forum terbuka. Selesai munaqasyah, ditentukanlah kelulusan. Kepada santri yang "lulus" dapat diberikan ijazah lisan maupun diploma alimiyyah atau sejenisnya. ${ }^{14}$

Evaluasi keberhasilan pengajaran di pesantren ditentukan oleh kemampuan mengajarkan kitab kuning kepada orang lain. Jika audiennya merasa puas, maka hal itu santri yang bersangkutan telah lulus. Sebagai legalisasi kelulusannya adalah restu kyai bahwa santri yang bersangkutan boleh pindah mempelajari kitab lain yang lebih tinggi tingkatannya dan boleh mengajarkan kitab yang telah dikuasai kepada orang lain. ${ }^{15}$ Kalaupun dikenal sistem pemberian ijazah, kompetensi lulusan santrinya diukur berdasarkan pada sejauhmana seorang santri telah menyelesaikan pelajarannya dengan baik tentang suatu kitab tertentu sehingga si santri tersebut dianggap menguasai dan mengajarkannya kepada orang lain. Dan menurut Dhofier, pemberian ijazah ini hanya dikeluarkan untuk santri-

\footnotetext{
${ }^{13}$ Husen Muhammad, op.cit., hal. 280-283

14 Ibid, hal. 283-284

15 Op.cit., hal. 145
}

santri tingkat tinggi dan mengenai kitabkitab besar dan masyhur.

Hasil penelitian Puslitbang Lektur Keagamaan tahun 2004 tentang pergeseran literatur keagamaan di pesantren salafiyah di pulau Jawa, menyebutkan adanya pergeseran-pergeseran dalam penggunaan literatur baik dari sisi materi, bidang kajian, penyampaian, dengan berbagai penyebabnya. Penelitian Puslitbang Lektur Keagamaan diteruskan tahun 2005 dengan judul "Pergeseran Literatur di Pondok Pesantren Salafiyah" sebagai lanjutan dari kajian yang sama pada tahun sebelumnya (2004). Penelitian ini di fokuskan pada 9 daerah dengan sampel 21 pesantren dengan pertimbangan bahwa pesantren ini masih dianggap bersifat salafiyah untuk daerah-daerahnya dan masih konsisten menggunakan pola-pola lama dengan literatur klasiknya. Temuan penelitian itu menyebutkan bahwa nilainilai salafiyah dalam menggunakan kitab kuning sangat dipegang teguh oleh pesantren, penghormatan atas sikap para ulama pesantren terdahulu masih tetap dianut, konsep tikrari, sawabit dan qauli dalam penggunaan kitab yang diaji masih tetap dilakukan. Oleh karenanya secara substansi dapat dikatakan tidak ada perubahan dalam penggunaan literaturnya kecuali dalam cara pembelajaranya yaitu menambah dengan cara klasikal dan tidak meninggalkan cara lama yaitu bandongan, sorogan, wetonan dan lalaran. Pergeseran dalam penggunaan literatur hanya bersifat teknis dan terbatas pada alih bidang kajian, bahasa terjemah, penambahan kitab dalam bahsul masail dan penerbitan majalah serta kajian kitab khusus atas keinginan masyarakat. Hal lain dari temuan penelitian tersebut berkaitan dengan pengaruh kitab kuning terhadap lingkungan pondok pesantren yang memperlihatkan adanya pengaruh yang nampak terutama dalam sikap antara santri dan kyai, kebersamaan, ketentraman, kepatuhan dan kerelaan. Hal-hal tersebut kadangkala merupa- 
kan kendala bagi lingkungan pesantren yang dianggap sebagai jumud dan agen kemunduran. Namun demikian tuduhan tersebut tidak semuanya tepat karena banyak para santri yang ada di pesantren mengikuti perkuliahan di perguruan tinggi agama atau umum yang berada di wilayahnya. ${ }^{16}$

Bruinessen membuat tingkat kesulitan kitab kuning. Untuk itu ia menggunakan nama-nama tingkatan madrasah, yaitu ibtidaiyah, tsanawiyah, aliyah dan khawash. Kitab-kitab fiqih yang diajarkan adalah: pada tingkat tsanawiyah yaitu, Taqrib, Safinah, Sullam al-Taufiq, Uqud alLujain, Mabadi Fiqhiyah, dan Fiqh Wadhih. Pada tingkat Aliyah, yaitu Fath Al-Qarib, Minhaj Al-Thalibin, Fathul Wahab, Mahalli, Tahrir. Kitab Kifayatul Akhyar diajarkan pada tingkat Tsanawiyah dan Aliyah. Kitab kuning I'anah Thalibin, Bajuri, Iqna, Minhaj al-Thullab, Minhajul Qawim, Kasifat al-Saja, Syarah Sittin, Muhadzab, dan Bughyat alMustarsyidin tidak disebutkan tingkat pengajarannya. ${ }^{17}$

Apa yang digambarkan Bruinessen di atas tentunya bukan berlaku untuk seluruh pesantren di Indonesia. Karena tingkat pengajaran kitab kuning di pesantren berbeda satu pesantren dengan pesantren yang lain. Istilah tingkat yang digunakan pun berbeda-beda. Ada yang menggunakan istilah tingkat itu mengadopsi sistem madrasah yang sudah ada seperti ibtidaiyah, tsanawiyah, aliyah seperti yang digunakan Bruinessen dalam studinya. Saat ini tingkatan pengajaran pada Pendidikan diniyah dan pesantren sudah diatur dalam PP No 55 Tahun 2007 tentang Pendidikan agama dan Pendidikan keagamaan. Dalam PP itu disebutkan ada tingkat dasar, menengah, dan tinggi. Selain itu ada istilah

16 Fadhal A.R. Bafadal dan Syatibi (ed.), Pergeseran Literatur di Pondok Pesantren Salafiyah, 2006, Jakarta, Puslitbang Lektur Keagamaan, Kemenag RI

17 Bruinessen, op.cit., hal. 115 tingkat awaliyah (ula), wustha, 'ulya, dan Ma'had Aly.

Pengajaran kitab-kitab fiqih dalam penelitian ini adalah proses belajar mengajar yang menggunakan kitab-kitab fiqih sebagai sumber belajarnya. Proses belajar mengajar kitab-kitab fiqih dalam penelitian ini difokuskan pada: (1) nama kitab-kitab fiqih (72 kitab) yang banyak diajarkan, (2) metode yang digunakan dalam pengajaran kitab-kitab fiqih, (3) jumlah pertemuan dalam pengajaran kitab-kitab fiqih, dan (4) tingkat pengajaran kitab-kitab fiqih.

Metode pengajaran kitab kuning adalah metode sorogan, bandongan, lalaran, dan diskusi. Sedangkan jumlah pertemuan pengajaran kitab-kitab fiqih adalah seberapa kali kitab-kitab fiqih tersebut diajarkan, apakah setiap hari, satu minggu satu kali, satu minggu dua kali, dan satu minggu tiga kali. Ada juga kitab-kitab fiqih tertentu diajarkan setiap pasaran. Arti pasaran di sini adalah dalam satu waktu (misalnya satu bulan) satu kitab fiqih tertentu ditamatkan. Selanjutnya, istilah yang digunakan untuk menyebut tingkat pengajaran kitab-kitab fiqih adalah tingkat ula, wustha, ulya dan ma'had Aly.

\section{Pondok Pesantren}

Pondok Pesantren adalah lembaga Pendidikan tradisional Islam untuk mempelajari, memahami, menghayati, dan mengamalkan ajaran Islam dengan menekankan pentingnya moral keagamaan sebagai pedoman perilaku sehari-hari.18 Dalam perkembangannya, pondok pesantren mengalami variasi dilihat dari orientasi dan serta strategi pembelajarannya. Ada tiga kategori pondok pesantren: pondok pesantren salafiyah, pondok pesantren khalafiyah atau ashriyah, dan pondok pesantren kombinasi.

18 Mastuhu, op.cit., hal 55 
Pondok pesantren salafiyah merupakan jenis pondok pesantren yang hanya menyelenggarakan atau mengutamakan pengajian kitab dan tidak menyelenggarakan Pendidikan formal, atau pondok pesantren yang berorientasi mengajarkan pengetahuan agama sepenuhnya (tafaquh fi addin), dengan metoda sorogan atau bandongan. Pondok pesantren salafiyah sering dikategorikan sebagai pondok pesantren tradisional karena menekankan pada pengajaran kitab kuning (karya-karya besar produk abad keemasan peradaban Islam pada abad 9-13 Masehi). Pesantren khalafiyah/Ashiriyah--yang juga disebut pondok pesantren modern--merupakan jenis pesantren yang hanya menyelenggarakan Pendidikan formal yang mengajarkan pengetahuan umum (yang dianggap dasar dan penting, seperti bahasa Inggeris, Bahasa Indonesia, dan pengetahuan umum lainnya) di samping pengetahuan agama. Di antara pondok pesantren khalafiyah, banyak pula pondok pesantren yang menyelenggarakan Pendidikan persekolahan dengan menggunakan kurikulum Depag atau Depdiknas. Sementara, pondok pesantren kombinasi merupakan jenis pondok pesantren yang belajar kitab kuning dan menyelenggarakan Pendidikan formal.

Pesantren yang dimaksud dalam penelitian ini adalah seluruh pondok pesantren yang terdata pada EMIS Kementerian Agama RI yang jumlahnya 24. 206 pada tahun 2008/2009. Semua pesantren ini dikategorikan oleh EMIS kementerian Agama RI ke dalam pesantren Salafiyah (12.477 pesantren atau 56\%), pesantren Ashriyah (3.165 pesantren atau 13\%), dan pesantren Kombinasi (7.564 pesantren atau $31 \%)$.

\section{KITAB-KITAB FIQIH YANG BANYAK DIAJARKAN DI PESANTREN}

Menurut Bruinessen, bidang fiqih merupakan satu disiplin ilmu yang paling banyak diajarkan di pesantren. Karena itu dari sekitar 900 judul kitab kuning yang beredar di pesantren, 20\% (sekitar 180 kitab) yang bersubstansikan fiqih.

Dalam survei ini, dari 72 kitab fiqih, kitab Taqrib menempati urutan teratas dengan frekuensi pengajaran sebesar 661 atau $(7,2 \%)$ dan kitab al-Majmuat ar-Rawiyah menempati urutan terbawah dengan frekuensi pengajaran sebesar 3 atau $(0,03 \%)$.

Jika diklasifikasikan ke dalam kelompok pengajaran kitab fiqih, yaitu: kelompok kitab yang sedikit diajarkan $(0,0 \%$ $2,4 \%)$, kelompok kitab yang cukup banyak diajarkan (2,5\%-4,8\%), dan kelompok kitab yang banyak diajarkan (4,9\%-8,4\%), Tabel 1 menunjukkan ada lima kitab fiqih yang termasuk kelompok kitab yang banyak diajarkan, yakni: Taqrib, Safinah al-Najah, Fath al-Muin, Fath al-Qarib, dan Sullam alTaufiq.

Tabel 1

Kelompok Kitab Yang Banyak Diajarkan

\begin{tabular}{|l|l|l|}
\hline \multicolumn{1}{|c|}{ Nama Kitab } & $\begin{array}{c}\text { Banyaknya Kyai } \\
\text { Mengajarkan }\end{array}$ & \multicolumn{1}{c|}{ Persentase (\%) } \\
\hline Taqrib & 661 & 7,21 \\
\hline Safinah al-Najah & 651 & 7,10 \\
\hline Fath al-Mu'in & 613 & 6,69 \\
\hline Fath al-Qarib & 607 & 6,62 \\
\hline Sullam al-Taufiq & 501 & 5,47 \\
\hline
\end{tabular}

Sumber: data survei pengajaran kitab kuning

Menurut Tabel 1, kitab Taqrib dan syarahnya Fath al-Qarib yang menurut Bruinessen sebagai kitab fiqih yang dahulu paling populer dan hampir tidak ada pesantren yang tidak menggunakan kedua kitab tersebut, saat ini masih tetap diajarkan di pesantren. Selain Taqrib dan Fath al-Qarib, yang termasuk kelompok kitab yang banyak diajarkan adalah Safinah al-Najah, Fath al-Mu'in dan Sullam al-Taufiq. Kitab Safinah al-Najah, misalnya, ditulis oleh Salim bin 'Abdullah bin Sumayr di Jakarta, setelah kedatangannya dari Makkah pada tahun $1850 \mathrm{M}$. Penulisnya sangat membenci tarekat yang pada masa itu berkembang di 
Jakarta dan sekitarnya. Dapat diperkirakan bahwa kehadiran Safinah pun dimaksudkan, antara lain, untuk mengembalikan umat pada syariat (Moctar, 1999: 244).

Tabel 2

Kelompok Kitab Yang Cukup Banyak Diajarkan

\begin{tabular}{|l|l|l|}
\hline Nama Kitab & $\begin{array}{l}\text { Banyaknya Kyai } \\
\text { Mengajarkan }\end{array}$ & $\begin{array}{l}\text { Persentase } \\
(\%)\end{array}$ \\
\hline Kasyifat al-Saja & 363 & 3,96 \\
\hline Kifayat al-Akhyar & 358 & 3,91 \\
\hline l'anah at-Thalibin & 310 & 3,38 \\
\hline Riyad al-Badi'ah & 273 & 2,98 \\
\hline Sulam al-Munajat & 272 & 2,97 \\
\hline Uqud al-Lujain & 251 & 2,74 \\
\hline Bidayah al-Hidayah & 250 & 2,73 \\
\hline Nasoih al-'Ibad & 243 & 2,65 \\
\hline
\end{tabular}

Sumber: data survei Pengajaran Kitab Kuning

Tabel 2 menunjukkan bahwa ada 8 kitab fiqih yang termasuk kelompok yang cukup banyak diajarkan. Kitab-kitab Kasyifat alSaja, Sulam al-Munajat dan Uqud al-Lujain merupakan produk ulama Indonesia. Kitab Kifayatul Al-Akhyar (Dimasyqi), kitab I'anah at-Thalibin (hasyiyah atas kitab Fath al-Mu'in) yang merupakan salah satu kitab fiqih otoritatif, dan kitab Riyadh alBadi'ah yang merupakan salah satu teks yang diperkenalkan kepada kaum Muslim Indonesia oleh Nawawi Banten. Selain 6 kitab fiqih diatas, kitab Bidayah al-Hidayah dan kitab Nasoih al-'Ibad juga termasuk kelompok kitab yang cukup banyak diajarkan di pesantren. Sedangkan kitab-kitab fiqih yang termasuk kelompok kitab yang sedikit diajarkan berjumlah 59 kitab. Kelima puluh sembilan kitab fiqih itu terdapat beberapa kitab fiqih yang tergolong kitab tinggi dan kitab otoritatif.

Mengaitkan dengan beberapa "keluarga" kitab fiqih Syafii dan hubungan antara anggota keluarga ini, yaitu Muharrar karangan Rafi'i, Taqrib (atau Mukhtashar) oleh Abu Syuja' Al-Isfahani, dan Qurrah Al-'Ain karangan Malibari, hanya beberapa kitab fiqih saja yang termasuk kelompok kitab yang banyak diajarkan. Sebagian besar kitab dari keluarga kitab fiqih Syafii dan hubungan antara anggota keluarga ini, berada di luar kelompok kitab yang banyak diajarkan. Berikut adalah frekuensi pengajaran masing-masing nama kitabkitab fiqih itu.

Kitab Muharrarnya Imam Rafii pertama-tama disingkat oleh Abu Zakariya Yahya bin Syaraf Al-Nawawi menjadi Minhaj At-Thalibin. Frekuensi pengajaran kitab Minhaj at-Thalibin sebesar 1,59\%. Kitab Minhaj at-Thalibin ini telah melahirkan banyak syarah, diantaranya lima yang paling penting yaitu: Kanz Al-Raghibin (Muhalli) yang frekuensi pengajarannya sebesar 0,29\%, Manhaj At-Thullab (Zakariya Anshari) sebesar 0,64\%, Tuhfah Al-Muhtaj (Ibn Hajar Al-Haitami) sebesar 0,42\%, Nihayatul Muhtaj (Samsudin Ramli) sebesar 0,47\%, dan Mughni Al-Muhtaj (Syarbini) sebesar $0,12 \%$.

Dari kitab Kanz al-Raghibin lahir hasyiyah Qalyubi dan 'Umaira. Dan Fath al-Wahab sebuah syarah karya Zakariya Anshari atas karangan sendiri Manhaj AlTullab, frekuensi pengajarannya sebesar 2,21\%. Mir'at Al-Tullab karya Abdurrauf Al-Singkili merupakan terjemahan Fath Al-Wahhab dalam bahasa Melayu sebesar 0,07\%. Kecuali Taqrib dan Fath al-Qarib dari keluarga Taqrib yang masuk kelompok kitab yang banyak diajarkan, kitab Iqna' (Khatib Syarbini) frekuensi pengajarannya sebesar $1,56 \%$. Hanya Fath al-Muin (syarah Qurrah al-'Ain) yang masuk kelompok kitab yang banyak diajarkan dari keluarga Qurrah al'Ain.

Nawawi Banten menulis syarah Qurrah al-'Ain yakni Nihayah al-Zain yang frekuensi pengajarannya sebesar 2,18\%. Kitab Tarsyih Al-Mustafidin karya Alwi Al-Saqqaf mendapat frekuensi sebesar 0,60\%.

Satu keluarga kitab fiqih lagi yaitu AlMuqaddimah Al-Hadramiyah karya Abdullah Ba-fadhl. Kitab ini frekuensi pengajaran sebesar 0,28\%. Ibnu Hajar Al-Haitami menulis syarah atas kitab ini, Minhaj alQawim yang frekuensi pengajaran sebesar 1,49\%. Dan kemudian mufti Syafi'i Madinah 
Sulaiman Al-Kurdi menulis catatan-catatan luas, Al-Hawasyi Al-Madaniyah, mendapat frekuensi pengajaran sebesar $0,10 \%$. Syarah lain dari Al-Muqaddimah Al-Hadramiyah yang ditulis Sa'id ibn M.Ba'syin yakni kitab Busyra Al-Karim mendapat frekuensi pengajaran sebesar $0,51 \%$. Sedangkan kitab Syarh 'ala Ba-Fadhl yang ditulis Mahfudz AlTarmasi, frekuensi pengajarannya sebesar $0,26 \%$.

Kitab Tahrir Tanqib li Al-Lubab fi Fiqh AlImam Al-Syafii karya Zakariya Al-Anshari mendapat frekuensi pengajaran sebesar $0,63 \%$. Sedangkan sebuah syarah atas Tahrirnya, yakni Tuhfah at-Tulab mendapat frekuensi pengajarannya sebesar 0,38\%. Syarah Riyadh Al-Badi'ah adalah Tsamar Al-Yaniah yang ditulis Nawawi Banten, frekuensi pengajarannya sebesar $0,28 \%$. Safinah as-Shalah sendiri yang disyarahi dalam Sullam Munajat frekuensi pengajarannya sebesar $0,54 \%$. Syarah Sittin adalah sebuah teks singkat tipe perukunan yang populer di Jawa pada abad ke-19, dan judulnya disebut dalam Serat Centini mendapat frekuensi pengajaran sebesar $1,61 \%$.

Bughyah al-Mustarsyidin adalah sebuah koleksi fatwa oleh ulama abad ke-19/20, yang dihimpun oleh Mufti Hadhramaut 'Abd Al-Rahman ibn Muhammad ibn Husain Ba'alawi sebesar 1,24\%. Kitab alFigh al-Wadih yang merupakan buku teks mutakhir dalam bahasa Arab sederhana dan ditulis ulama Minangkabau, Mahmud Yunus, frekuensi pengajarannya sebesar 1,31\%. Kitab Bidayatul Mujtahid karya Ibnu Rusyd yang tergolong pengaruh gerakan modernis frekuensi pengajarannya sebesar $0,52 \%$.
Tabel 3: Lima Kitab Fiqh Teratas Yang Diajarkan di Masing-Masing Propinsi

\begin{tabular}{|c|c|c|c|c|c|c|}
\hline \multirow{2}{*}{ No } & \multirow{2}{*}{$\begin{array}{l}\text { Propin- } \\
\text { si }\end{array}$} & \multicolumn{5}{|c|}{ Lima Kitab Fiqih Teratas Yang Diajarkan } \\
\hline & & 1 & 2 & 3 & 4 & 5 \\
\hline 1 & Jabar & $\begin{array}{l}\text { Safinah } \\
\text { al-Najah }\end{array}$ & Taqrib & $\begin{array}{l}\text { Fath al- } \\
\text { Mu'in }\end{array}$ & $\begin{array}{l}\text { Sullam } \\
\text { al-Taufiq }\end{array}$ & $\begin{array}{l}\text { Fath al- } \\
\text { Qarib }\end{array}$ \\
\hline 2 & Banten & Taqrib & $\begin{array}{l}\text { Fath al- } \\
\text { Qarib }\end{array}$ & $\begin{array}{l}\text { Fath al- } \\
\text { Mu'in }\end{array}$ & $\begin{array}{l}\text { Safinah } \\
\text { al-Najah }\end{array}$ & $\begin{array}{l}\text { Kasyifat } \\
\text { al-Saja }\end{array}$ \\
\hline 3 & Jatim & Taqrib & $\begin{array}{l}\text { Fath al- } \\
\text { Qarib }\end{array}$ & $\begin{array}{l}\text { Safinah } \\
\text { al-Najah }\end{array}$ & $\begin{array}{l}\text { Sullam } \\
\text { al-Taufig }\end{array}$ & $\begin{array}{l}\text { Fath al- } \\
\text { Mu'in }\end{array}$ \\
\hline 4 & Jateng & $\begin{array}{l}\text { Fath al- } \\
\text { Qarib }\end{array}$ & $\begin{array}{l}\text { Safinah } \\
\text { al-Najah }\end{array}$ & Taqrib & $\begin{array}{l}\text { Fath al- } \\
\text { Mu'in }\end{array}$ & $\begin{array}{l}\text { Sullam } \\
\text { al-Taufiq }\end{array}$ \\
\hline 5 & Sumsel & \begin{tabular}{|l|} 
Fath al- \\
Qarib \\
\end{tabular} & \begin{tabular}{|l} 
Fath al- \\
Mu'in \\
\end{tabular} & \begin{tabular}{|l|l|} 
Safinah \\
al-Najah
\end{tabular} & Taqrib & $\begin{array}{l}\text { Sullam } \\
\text { al-Taufiq }\end{array}$ \\
\hline 6 & NAD & \begin{tabular}{|l|} 
Fath al- \\
Mu'in \\
\end{tabular} & Taqrib & $\begin{array}{l}\text { I'anah } \\
\text { athalibin }\end{array}$ & $\begin{array}{l}\text { Fath al- } \\
\text { Qarib }\end{array}$ & $\begin{array}{l}\text { Hasyiyah } \\
\text { Bajuri }\end{array}$ \\
\hline 7 & $\begin{array}{l}\text { Lam- } \\
\text { pung }\end{array}$ & \begin{tabular}{|l|} 
Fath al- \\
Qarib
\end{tabular} & $\begin{array}{l}\text { Safinah } \\
\text { al-Najah }\end{array}$ & \begin{tabular}{|l|} 
Fath al- \\
Mu'in
\end{tabular} & Taqrib & $\begin{array}{l}\text { Sullam al- } \\
\text { Munajat }\end{array}$ \\
\hline 8 & NTB & $\begin{array}{l}\text { Fath al- } \\
\text { Qarib }\end{array}$ & Taqrib & \begin{tabular}{|l|} 
Safinah \\
al-Najah
\end{tabular} & \begin{tabular}{|l} 
Fath al- \\
Mu'in
\end{tabular} & $\begin{array}{l}\text { Kifayatu } \\
\text { al-Akhyar }\end{array}$ \\
\hline 9 & Kalsel & \begin{tabular}{|l|} 
Fath al- \\
Mu'in
\end{tabular} & Taqrib & $\begin{array}{l}\text { Fath al- } \\
\text { Qarib }\end{array}$ & $\begin{array}{l}\text { Hasyiyah } \\
\text { Bajuri }\end{array}$ & $\begin{array}{l}\text { I'anah } \\
\text { athalibin }\end{array}$ \\
\hline 10 & DIY & $\begin{array}{l}\text { Safinah } \\
\text { al-Najah }\end{array}$ & $\begin{array}{l}\text { Sullam } \\
\text { al-Taufiq }\end{array}$ & Taqrib & $\begin{array}{l}\text { Dirarulba- } \\
\text { hiyah }\end{array}$ & $\begin{array}{l}\text { Fath al- } \\
\text { Qarib }\end{array}$ \\
\hline 11 & Kalbar & $\begin{array}{l}\text { Safinah } \\
\text { al-Najah }\end{array}$ & Taqrib & $\begin{array}{l}\text { Fath al- } \\
\text { Qarib }\end{array}$ & $\begin{array}{l}\text { Sullam } \\
\text { al-Taufig }\end{array}$ & $\begin{array}{l}\text { Fath al- } \\
\text { Mu'in }\end{array}$ \\
\hline 12 & Jambi & $\begin{array}{l}\text { Safinah } \\
\text { al-Najah }\end{array}$ & Taqrib & $\begin{array}{l}\text { Fath al- } \\
\text { Oarib }\end{array}$ & $\begin{array}{l}\text { Sullam } \\
\text { al-Taufig }\end{array}$ & $\begin{array}{l}\text { Fath al- } \\
\text { Mu'in }\end{array}$ \\
\hline 13 & Sumbar & \begin{tabular}{|l|} 
Fath al- \\
Mu'in \\
\end{tabular} & \begin{tabular}{|l|l|} 
I'anah \\
athalibin
\end{tabular} & Taqrib & $\begin{array}{l}\text { Fath al- } \\
\text { Qarib }\end{array}$ & $\begin{array}{l}\text { Minhaj al- } \\
\text { Thalibin } \\
\end{array}$ \\
\hline 14 & Sumut & $\begin{array}{l}\text { Fath al- } \\
\text { Mu'in }\end{array}$ & $\begin{array}{l}\text { Hasyiyah } \\
\text { Bajuri }\end{array}$ & $\begin{array}{l}\text { Al-Tadhib } \\
\text { fi Adilati } \\
\text { Matn Al- } \\
\text { Goyah wa } \\
\text { Taqrib }\end{array}$ & $\begin{array}{l}\text { Kifayatul } \\
\text { al-Akhyar }\end{array}$ & $\begin{array}{l}\text { I'anah } \\
\text { athalibin }\end{array}$ \\
\hline 15 & Sulsel & $\begin{array}{l}\text { Fath al- } \\
\text { Mu'in }\end{array}$ & $\begin{array}{l}\text { Fath al- } \\
\text { Qarib }\end{array}$ & $\begin{array}{l}\text { Tarikh } \\
\text { Tasyri' }^{\prime}\end{array}$ & $\begin{array}{l}\text { Al-Fiqh } \\
\text { 'ala Maza- } \\
\text { hib al- } \\
\text { Arba'ah }\end{array}$ & $\begin{array}{l}\text { Safinah } \\
\text { al-Najah }\end{array}$ \\
\hline
\end{tabular}

Dilihat dari masing-masing propinsi, Tabel 3 menunjukkan kitab-kitab fiqih yang menempati urutan teratas terlihat berbeda. Kecuali di Banten dan Jatim yang sama secara nasional menempatkan kitab Taqrib sebagai urutan teratas. Kitab Safinah alNajah menempati urutan teratas di Jabar, DIY, Kalbar dan Jambi. Sedangkan di Jateng, Sumsel, Lampung, dan NTB menempatkan kitab Fath al-Qarib sebagai urutan teratas. Kitab Fath al-Mu'in menempati urutan teratas di NAD, Kalsel, Sumbar, Sumut, dan Sulsel.

Dilihat dari kelompok kitab yang banyak diajarkan secara nasional (Taqrib, Safinah al-Najah, Fath al-Mu'in, Fath al-Qarib, dan Sullam al-Taufiq) di beberapa propinsi juga terjadi, yakni: Jabar, Jateng, Jatim, Sumsel, Kalbar, dan Jambi. Sedangkan di Banten kitab Sullam al-Taufiq digeser oleh 
kitab Kasyifat as-Saja. Di NAD dan Kalsel kitab I'anah at-Thalibin dan Hasyiyah Bajuri menggeser kitab Safinah al-Najah dan Sullam al-Taufiq. Di Lampung kitab Sullam al-Taufiq digeser oleh kitab Sullam al-Munajat. Di NTB kitab Kifayat al-Akhyar menggeser kitab Sullam al-Taufiq. Di Sumbar kitab Safinah al-Najah dan Sullam al-Taufiq digeser oleh kitab I'anah at-Thalibin dan Minhaj atThalibin. Di Sulsel kitab Tarikh Tasyri dan Al-Fiqh 'ala Mazahib al-Arba'ah menggeser kitab Taqrib dan Sullam al-Taufiq. Selain Fath al-Mu'in, di Sumut yang termasuk kelompok kitab yang banyak diajarkan adalah: Hasyiyah Bajuri, Al-Tadhib fi Adilati Matn Al-Ghoyah wa Taqrib, Kifayat al-Akhyar, dan I'anat at-Thalibin.

Tabel 4: Jumlah Kitab Fiqih Diajarakan atau Tidak diajarkan di Masing-Masing Propinsi

\begin{tabular}{|l|l|c|c|}
\hline No & \multicolumn{1}{|c|}{ Propinsi } & Diajarkan & Tdk Diajarkan \\
\hline 1 & Jabar & 72 & 0 \\
\hline 2 & Banten & 69 & 3 \\
\hline 3 & Jatim & 68 & 4 \\
\hline 4 & Jateng & 67 & 5 \\
\hline 5 & Sumsel & 54 & 18 \\
\hline 6 & NAD & 49 & 23 \\
\hline 7 & Lampung & 47 & 25 \\
\hline 8 & NTB & 45 & 27 \\
\hline 9 & Kalsel & 43 & 29 \\
\hline 10 & DIY & 42 & 30 \\
\hline 11 & Kalbar & 34 & 38 \\
\hline 12 & Jambi & 17 & 55 \\
\hline 13 & Sumbar & 17 & 55 \\
\hline 14 & Sumut & 17 & 55 \\
\hline 15 & Sulsel & 17 & 55 \\
\hline
\end{tabular}

Berapa jumlah kitab fiqih yang diajarkan atau tidak diajarkan di masingmasing propinsi. Ada perbedaan jumlah kitab fiqih yang diajarkan atau tidak diajarkan di masing-masing propinsi. Tabel 4 menunjukkan bahwa 72 kitab yang disurvei seluruhnya diajarkan di pesantrenpesantren di Jawa Barat. Kitab-kitab fiqih yang tidak diajarkan di masing-masing propinsi adalah: Banten (3 kitab), Jatim (4 kitab), Jateng (5 kitab), Sumsel (18 kitab),
NAD (23 kitab), Lampung (25 kitab), NTB (27 kitab), Kalsel (29 kitab), DIY (30 kitab), Kalbar (38 kitab), Jambi, Sumbar, Sumut, dan Sulsel (55 kitab). Propinsi-propinsi yang menjadi basis pesantren seperti Jatim, Jateng, dan Banten memperlihatkan adanya kitab-kitab fiqih yang tidak diajarkan. Pesantren sasaran di Jatim tidak mengajarkan 4 kitab fiqih, yaitu: Nihayah al-Muhtaj, alMajmuat al-Rawiyah, al-Fiqh 'ala Mazahib alKhamsah, dan Mughni al-Muhtaj. Pesantren sasaran di Jateng tidak mengajarkan 5 kitab fiqih, yaitu: al-Majmuat al-Rawiyah, Tuhfah al-Infinaniyah, Sabil al-Muhtadin, Mir'at al-Thullab, dan Mughni al-Muhtaj. Pesantren sasaran di Banten tidak mengajarkan 3 kitab fiqih, yaitu: al-Majmuat al-Rawiyah, Mughni al-Muhtaj, dan Tanwir al-Hija'.

Tabel 5: Lima Kitab Fiqih Teratas Yang Diajarkan di Masing-Masing Tipologi Pesantren

\begin{tabular}{|l|l|l|l|l|l|l|}
\hline \multirow{2}{*}{ No } & \multirow{2}{*}{ Propinsi } & \multicolumn{5}{|l|}{ Lima Kitab Fiqih Teratas Yang Diajarkan } \\
\cline { 3 - 7 } & 1 & 2 & 3 & 4 & 5 \\
\hline 1 & Salafiyah & Taqrib & $\begin{array}{l}\text { Safinah } \\
\text { al- } \\
\text { Najah }\end{array}$ & $\begin{array}{l}\text { Fath al- } \\
\text { Mu'in }\end{array}$ & $\begin{array}{l}\text { Fath al- } \\
\text { Qarib }\end{array}$ & $\begin{array}{l}\text { Sullam } \\
\text { al- } \\
\text { Taufiq }\end{array}$ \\
\hline 2 & Kombinasi & Taqrib & $\begin{array}{l}\text { Fath al- } \\
\text { Mu'in }\end{array}$ & $\begin{array}{l}\text { Safinah } \\
\text { al- } \\
\text { Najah }\end{array}$ & $\begin{array}{l}\text { Fath al- } \\
\text { Qarib }\end{array}$ & $\begin{array}{l}\text { Sullam } \\
\text { al- } \\
\text { Taufiq }\end{array}$ \\
\hline 3 & Ashriyah & $\begin{array}{l}\text { Fath al- } \\
\text { Qarib }\end{array}$ & $\begin{array}{l}\text { Safinah } \\
\text { al- } \\
\text { Najah }\end{array}$ & $\begin{array}{l}\text { Fath al- } \\
\text { Mu'in }\end{array}$ & Taqrib & $\begin{array}{l}\text { Kifayah } \\
\text { al- } \\
\text { Akhyar }\end{array}$ \\
\hline
\end{tabular}

Berdasarkan tipologi pesantren, Tabel 5 menunjukkan bahwa kitab Taqrib menempati urutan teratas di pesantren Salafiyah dan pesantren Kombinasi, dan kitab Fath al-Qarib menempati urutan teratas di pesantren ashriyah. Dilihat dari lima urutan kitab fiqih teratas di masing-masing tipologi, kitab Sullam al-Taufiq termasuk pada tipologi salafiyah dan kombinasi. Kitab Sullam at-Taufiq tidak termasuk ke dalam urutan lima teratas pada tipologi ashriyah, dan sebagai gantinya adalah kitab Kifayah al-Akhyar.

Sebagian besar kitab fiqih-jumlahnya 67 kitab-yang tidak termasuk kelompok kitab yang banyak diajarkan 
mengindikasikan adanya sebuah bentuk atau pola pengajaran kitab-kitab fiqih, yaitu: semakin kitab-kitab fiqih itu tingkat tinggi, maka sedikit pesantren yang mengajarkannnya. Sebaliknya, semakin kitabkitab fiqih itu tingkat rendah, maka banyak pesantren yang mengajarkannya.

Temuan survei ini membenarkan asumsi tradisi pengajaran kitab kuning yang sudah lama dipraktekkan, yaitu: pertama, kitab kuning elementer banyak diajarkan, dan kitab kuning tinggi menjadi rujukan kaum santri tingkat tinggi atau ustadz atau kyai dalam forum pengkajian kitab seperti bahtsul masail. Kedua, pengajaran kitab kuning di pesantren tidak variatif (variasinya yang sedikit). Kitab kuning tidak perlu diajarkan semua, kyai pesantren cukup mengajarkan beberapa kitab yang perlu dikuasai, setelah menguasai santri dibebaskan untuk mempelajari sendiri.

Survei ini juga sekaligus membantah asumsi yang menyatakan bahwa kitabkitab-kitab fiqih yang diajarkan mengalami perubahan. Artinya dari dulu sampai sekarang kitab-kitab fiqih yang diajarkan tidak mengalami perubahan. Kitab-kitab fiqih seperti Taqrib, Safinah al-Najah, Fath al-Muin, Fath al-Qarib, dan Sullam al-Taufiq itulah yang dalam hasil survei ini termasuk kelompok kitab yang banyak diajarkan dan juga termasuk kitab dasar-kecuali kitab Fathul Mu'in-yang dari dahulu sampai sekarang diajarkan. Sedangkan sebagian besar kitab-kitab menengah dan tinggi yang dalam hasil survei ini termasuk kelompok yang sedikit diajarkan menjadi referensi saja. Namun demikian, bagaimana kualitas penguasaan santri terhadap kitabkitab fiqih diatas. Apakah ada perbedaan antara dahulu dengan sekarang terhadap penguasaan kitab-kitab fiqih tersebut. Tentunya perlu dilakukan kajian-kajian selanjutnya. Misalnya membandingkan kemampuan santri di pesantren dalam penguasaan kitab-kitab fiqih dengan pendekatan sejarah (time seris) antara sebelum pengadopsian sistem Pendidikan formal dengan setelah pengadopsian sistem Pendidikan formal.

\section{METODE PENGAJARAN KITAB- KITAB FIQIH}

Selama waktu yang panjang, pesantren telah memperkenalkan beberapa metode pengajaran kitab kuning, yaitu bandongan atau weton, sorogan, lalaran atau hapalan, dan diskusi atau musyawarah. Semua metode ini tetap dipertahankan dalam sistem klasikal (madrasah) maupun non klasikal (halaqoh).

Metode weton atau bandongan atau balagan adalah cara penyampaian kitab kuning dimana seorang guru, kiai, atau ustadz membacakan dan menjelaskan isi kitab kuning, sementara santri, murid, atau siswa mendengarkan, memberi makna, dan menerima. Metode sorogan adalah murid membaca dan guru mendengarkan sambil memberi catatan, komentar, atau bimbingan bila diperlukan. Metode diskusi atau musyawarah adalah belajar bersama secara diskusi untuk saling mencocokokan pemahaman mengenai arti terjemahan dari isi kitab. Hapalan atau lalaran adalah belajar sendiri secara individual dengan jalan menghafal, biasanya dilakukan dimana saja misalnya di serambi masjid atau serambi kamar.

Grafik 1: Metode Pengajaran Kitab-Kitab Fiqih




Grafik 1 menunjukan bahwa pengajaran 72 kitab fiqih rata-rata menggunakan metode bandongan yang menempati urutan teratas. Urutan selanjutnya adalah metode sorogan; metode sorogan dan bandongan; metode diskusi; metode lalaran; metode bandongan dan diskusi; metode sorogan dan lalaran; metode sorogan dan diskusi; metode sorogan, bandongan, dan diskusi; dan metode lalaran dan diskusi.

Kitab-kitab fiqih apa saja yang menempatkan metode bandongan sebagai urutan teratas. Metode bandongan menempati urutan teratas hampir di semua pengajaran kitab fiqih, kecuali kitab al-Fiqh 'ala madzahib al-khomsah dan Mughni al-Muhtaj yang metode pengajaran teratasnya adalah metode sorogan, dan kitab Manhaj at-Tullab dan kitab Tuhfah al-Muhtaj yang metode pengajaran teratasnya adalah metode sorogan dan bandongan.

Meskipun tidak menempati urutan teratas, metode diskusi menempati urutan kedua pada 10 pengajaran kitab fiqih, yaitu: Tarsyih al-Mustafidin, Nihayah al-Muhtaj, Tausyikh Ibn Wahaj, Al-Mahali, Qaidah al-Fiqhiyah, Mizan al-Kubra, Bidayah alMujtahid, Tuhfah al-Infinaniyah, dan Mughni al-Muhtaj. Metode diskusi juga menempati urutan ketiga pada 10 pengajaran kitab fiqih, yaitu: Tuhfah al-Ahbab, Samar alYani'ah, Inaratuddaji, Zuhrah al-Bahiyah, AlTadhib fi Adilati Matn al-Ghoyah wa al-Taqrib, Mabadi al-Fiqhiyah,Tahrir, Muhadzab, Sabil alMuhtadin, dan Hidayat al-Muhtadi.

Metode lalaran yang juga tidak menempati urutan teratas pada seluruh kitab, tetapi metode ini menempati urutan kedua pada 6 pengajaran kitab fiqih, yaitu: Dirar al-Bahiyah, Mawahib as-Shamad, Inaratuddaji, Zuhrah al-Bahiyah, Mir'at alTullab, dan Tanwir al-Hija'. Metode Ialaran juga menempati urutan ketiga pada 3 pengajaran kitab fiqih, yaitu: Zubad, Nailu al-Author, dan Safinat as-Shalah.
Tabel 6: Lima Urutan Teratas Metode Pengajaran Pada kelompok kitab Fiqih yang Banyak Diajarkan

\begin{tabular}{|c|c|c|c|c|c|c|}
\hline \multirow{2}{*}{ No } & \multirow{2}{*}{$\begin{array}{l}\text { Nama } \\
\text { Kitab }\end{array}$} & \multicolumn{5}{|c|}{ Lima Urutan Teratas Metode Yang Digunakan } \\
\hline & & 1 & \| & III & IV & V \\
\hline 1 & Taqrib & bandongan & Sorogan & $\begin{array}{l}\text { sorogan } \\
\text { dan ban- } \\
\text { dongan }\end{array}$ & Lalaran & $\begin{array}{l}\text { bandongan } \\
\text { dan diskusi }\end{array}$ \\
\hline 2 & \begin{tabular}{|l|} 
Safinah \\
an-Najah
\end{tabular} & bandongan & Sorogan & $\begin{array}{l}\text { sorogan } \\
\text { dan ban- } \\
\text { dongan }\end{array}$ & Lalaran & $\begin{array}{l}\text { sorogan } \\
\text { dan lalaran }\end{array}$ \\
\hline 3 & \begin{tabular}{|l|} 
Fath \\
al-Muin
\end{tabular} & bandongan & Sorogan & $\begin{array}{l}\text { sorogan } \\
\text { dan ban- } \\
\text { dongan }\end{array}$ & Diskusi & $\begin{array}{l}\text { bandongan } \\
\text { dan diskusi }\end{array}$ \\
\hline 4 & $\begin{array}{l}\text { Fath al- } \\
\text { Qarib }\end{array}$ & bandongan & Sorogan & $\begin{array}{l}\text { sorogan } \\
\text { dan ban- } \\
\text { dongan }\end{array}$ & Lalaran & Diskusi \\
\hline & & & & & & \\
\hline 5 & $\begin{array}{l}\text { Sullam } \\
\text { at-Taufiq }\end{array}$ & bandongan & Sorogan & $\begin{array}{l}\text { sorogan } \\
\text { dan ban- } \\
\text { dongan }\end{array}$ & Lalaran & Diskusi \\
\hline
\end{tabular}

Bagaimana dengan metode pengajaran pada kelompok kitab fiqih yang banyak diajarkan. Tabel 6 menunjukkan metode bandongan menempati urutan teratas pada kelompok kitab fiqih yang banyak diajarkan: Taqrib, Safinah an-Najah, Fath al-Mu'in, Fath al-Qarib dan Sullam at-Taufiq. Urutan kedua dan ketiga ditempati metode sorogan dan "metode sorogan dan bandongan". Metode lalaran menempati urutan keempat pada kelompok kitab yang banyak diajarkan, kecuali kitab Fath al-Mu'in yang menggunakan metode diskusi. Urutan kelima ditempati metode yang berbeda. Untuk kitab Taqrib dan Fath al-Mu'in menggunakan metode bandongan dan diskusi. Untuk kitab Fath al-Qarib dan Sullam atTaufiq mengunakan metode diskusi. Dan untuk kitab Safinah an-Najah menggunakan metode "sorogan dan lalaran".

Deskripsi diatas memberikan gambaran bahwa dari dulu sampai sekarang metode bandongan dan sorogan ini masih dominan digunakan dalam pengajaran kitab-kitab fiqih. Masih adanya metode lalaran yang digunakan dalam pengajaran kitab-kitab fiqih menjelaskan bahwa masih adanya pengaruh ahl al-hadits dalam pengajaran kitab-kitab fiqih. Meskipun belum dominan penggunaan metode diskusi dalam pengajaran kitab-kitab fiqih, metode 
ini ke depan kecenderungannya akan terus meningkat.

\section{JUMLAH PERTEMUAN PENGAJAR- AN KITAB-KITAB FIQIH}

Berapa kali kitab-kitab fiqih diajarkan; setiap hari, seminggu sekali, seminggu dua kali, seminggu tiga kali, atau setiap pasaran. Grafik 2 menunjukkan bahwa dari 72 kitab fiqih, 31 kitab (43\%) diajarkan tiap hari yang menempati urutan teratas, 35 kitab (49\%) diajarkan 1 minggu 1 kali yang menempati urutan teratas, 4 kitab (5\%) diajarkan 1 minggu 2 kali yang menempati urutan teratas, dan 2 kitab (3\%) diajarkan setiap kegiatan pasaran yang menempati urutuan teratas. Data ini menunjukkan bahwa kitab fiqih diajarkan 1 minggu 1 kali jumlahnya terbanyak dibanding dengan jumlah kitab fiqih yang diajarkan setiap hari, 1 minggu 2 kali, dan pasaran.

\section{Grafik 2:}

Jumlah Pertemuan Pengajaran Kitab-Kitab Fiqih

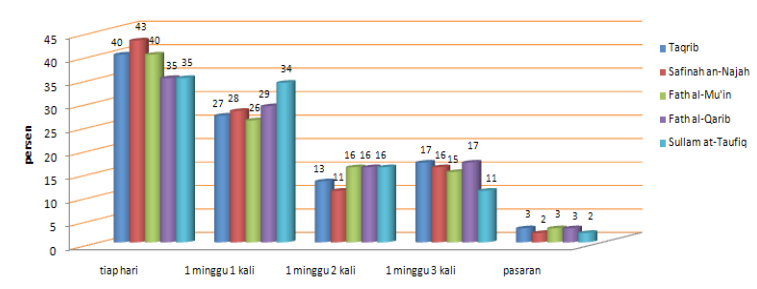

Bagaimana dengan jumlah pertemuan pengajaran pada kelompok kitab fiqih yang banyak diajarkan (Taqrib, Safinah al-Najah, Fath al-Muin, Fath al-Qarib, dan Sullam al-Taufiq). Grafik 3 menunjukkan bahwa kelima kitab fiqih itu diajarkan setiap hari sebagai urutan teratas.
Grafik 3:

Jumlah Pertemuan Pengajaran

Kelompok Kitab Fiqih Yang Banyak

Diajarkan

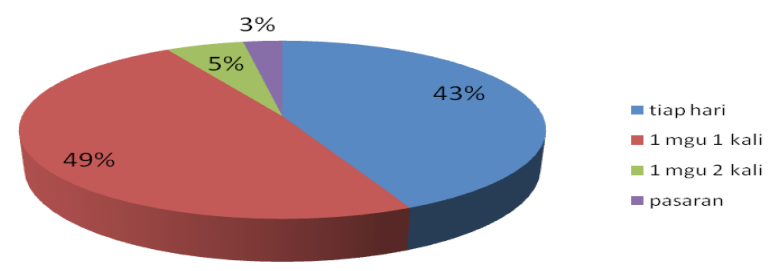

Dari lima kitab-kitab fiqih itu, Safinah an-Najah menempati urutan teratas. Kitab Taqrib dan Fathu al-Mu'in menempati urutan kedua. Adapun kitab Fathu al-Qarib dan Sullam at-Taufiq menempati urutan ketiga. Kitab Sullam at-Taufiq antara diajarkan tiap hari dan 1 minggu 1 kali tidak jauh perbedaannya.

\section{TINGKAT PENGAJARAN KITAB-KI- TAB FIQIH}

Untuk menentukan tingkat apa (ula, wustha, ulya dan ma'had aly) kitab-kitab fiqh itu diajarkan. Pertama-tama, nama kitab-kitab fiqih dilihat seberapa banyak pesantren (kyai) mengajarkannya. Kemudian dari jumlah pesantren yang mengajarkan dilihat berapa pilihan pesantren (kyai) antara yang menginginkan adanya jenjang dengan yang tidak berjenjang. Jika pilihan kyai lebih banyak pada opsi berjenjang dari pada opsi tidak berjenjang maka suatu kitab tersebut akan ditentukan sebagai kitab yang akan dijenjangkan. Sebaliknya, jika pilihan kyai lebih banyak pada opsi tidak berjenjang maka suatu kitab tertentu tidak dijenjangkan.

Dari 72 kitab fiqih, 55 kitab dijenjangkan dan 17 kitab tidak dijenjangkan. Kitab-kitab fiqih yang termasuk kategori dijenjangkan, selanjutnya ditentukan pada jenjang apa diajarkannya. Penentuan satu kitab tertentu masuk jenjang tertentu didasarkan pada pilihan terbanyak kyai terhadap 
jumlah kitab-kitab fiqih. Tiga kitab pilihan terbanyak akan diambil menjadi pilihan tingkat pengajaran kitab kuning. Alasan pemilihan tiga kitab pilihan terbanyak untuk memberikan alternatif bagi penentuan pengakuan kesetaraan Pendidikan pesantren berbasis pengajaran kitabkitab fiqih.

Tabel 7:

Tingkat Pengajaran Kitab Fiqih

\begin{tabular}{|l|l|l|l|}
\hline \multirow{2}{*}{ Tingkat } & \multicolumn{3}{|c|}{ Nama Kitab } \\
\cline { 2 - 4 } & \multicolumn{1}{|c|}{ I } & \multicolumn{1}{|c|}{ II } & \multicolumn{1}{c|}{ III } \\
\hline Ula & $\begin{array}{l}\text { Safinah al- } \\
\text { Najah }\end{array}$ & Taqrib & $\begin{array}{l}\text { Mabadiu al- } \\
\text { Fiqhiyah }\end{array}$ \\
\hline Wustha & Fath al-Qarib & Taqrib & $\begin{array}{l}\text { Sullam at- } \\
\text { Taufiq }\end{array}$ \\
\hline 'Ulya & Fath al-Mu'in & $\begin{array}{l}\text { I'anah at- } \\
\text { Thalibin }\end{array}$ & Fath al-Qarib \\
\hline Ma'had aly & Fath al-Mu'in & $\begin{array}{l}\text { Fath al-Wah- } \\
\text { hab }\end{array}$ & $\begin{array}{l}\text { l'anah at- } \\
\text { Thalibin }\end{array}$ \\
\hline
\end{tabular}

Tabel 7 diatas menunjukkan bahwa kitab Safinah al-Najah, Taqrib, dan Mabadiu al-Fiqhiyah diajarkan pada jenjang ula. Kitab Fath al-Qarib, Taqrib, dan Sullam at-Taufiq diajarkan pada jenjang wustha. Adapun jenjang 'ulya, kitab yang diajarkan adalah: Fath al-Mu'in, I'anah at-Thalibin, dan Fath al-Qarib. Sedangkan untuk jenjang Ma'had Aly, kitab-kitab fiqih yang diajarkan adalah: Fath al-Mu'in, Fath al-Wahhab, dan I'anah at-Thalibin. Ada suatu kitab yang terus menerus diajarkan di berbagai tingkat seperti kitab-kitab Taqrib, Fath al-Qarib, Fath al-Mu'in, dan l'anah at-Thalibin.

Data tentang tingkatan pengajaran kitab fiqih ini menguatkan sekaligus meruntuhkan beberapa temuan studi Bruinessen tentang kitab kuning yang dilakukan tahun 1980-an. Dalam fiqih, Bruinesen memasukan kitab-kitab Taqrib, Safinah, Sullam al-Taufiq, Uqud al-Lujain, Mabadi Fiqhiyah, dan Fiqh Wadhih untuk tingkat tsanawiyah. Hasil survei ini memasukan tiga kitab dari lima kitab fikih, yakni Safinah,Taqrib, dan Mabadiu al-Fiqhiyah untuk tingkatan ula. Kitab Taqrib dan Sullam al-Taufiq untuk tingkatan wustha.
Pada tingkat Aliyah, yaitu Fath AlQarib, Minhaj Al-Thalibin, Fathul Wahab, Mahalli, Tahrir sebagaimana temuan Bruinesen, hanya Fathul Muin yang termasuk tingkatan 'ulya. Meskipun keterpilihannya kepada tingkatan 'ulya, kitab-kitab Fathul Wahab, Mahalli, Tahrir keterpelihan kepada tingkatan itu masingmasing hanya sebanyak 50 pesantren untuk fathul wahab, 28 pesantren untuk Mahalli, dan 13 pesantren untuk tahrir.

Kitab I'anah Thalibin, Bajuri, Iqna, Manhaj al-Thullab, Minhajul Qawim, Kasifat al-Saja, Syarah Sittin, Muhadzab, dan Bughyat al-Mustarsyidin tidak disebutkan oleh Bruinessen tingkat pengajarannya, temuan survei memasukan I'anah at-Thalibin, Iqna, Manhaj al-Thullab, dan Minhajul Qawim ke tingkatan ‘ulya.

\section{PENUTUP}

\section{Kesimpulan}

1. Kelompok kitab fiqih yang banyak diajarkan adalah kitab-kitab fiqih standar. Sedangkan kitab-kitab fiqih menengah dan tinggi atau otoritatif termasuk ke dalam kelompok kitab yang cukup banyak dan sedikit diajarkan. Temuan survei ini membenarkan dan memperkuat asumsi tradisi pengajaran kitab kuning di pesantren yang sudah lama diperaktekkan.

2. Metode bandongan masih mendominasi metode pengajaran kitab-kitab fiqih di pesantren dibandingkan dengan metode-metode lain. Masih adanya metode lalaran yang digunakan dalam pengajaran kitab fiqih menjelaskan bahwa pengaruh ahl alhadits dalam pengajaran kitab fiqih masih ada. Meskipun belum dominan penggunaan metode diskusi dalam pengajaran kitab fiqih, metode ini ke depan kecenderungannya akan terus meningkat.

3. Kitab fiqih diajarkan 1 minggu 1 kali yang menempati urutan teratas 
jumlahnya terbanyak dibanding dengan jumlah kitab fiqih yang diajarkan setiap hari, 1 minggu 2 kali, dan pasaran.

4. Kitab-kitab fiqih diajarkan baik berjenjang maupun tidak berjenjang. Tetapi sebagian besar kitab fiqih perlu dijenjangkan. Terdapat perbedaan penjenjangan beberapa kitab fiqih antara temuan Bruinessen dengan hasil survei ini.

\section{Rekomendasi}

1. Rendahnya kuantitas (variasi kitab) pengajaran kitab-kitab fiqih dengan melihat frekuensi keterpilihan kitab yang diajarkan, kami menyarankan:

a. Pimpinan Pesantren (kyai) mengusahakan upaya kongkrit untuk meningkatkan mutu pengajaran kitab-kitab fiqih dalam hal kualitas penguasaan kitab-kitab fiqih. Peningkatan mutu pengajaran itu dimulai oleh kyai sebagai pengajar sehingga mempengaruhi terhadap peningkatan kualitas pengajaran kitab fiqih baik ustadz maupun santri. Dan ustadz yang direkrut untuk mengajar pesantren harus mampu mengajarkan kitab-kitab fiqih.

b. Kepada Direktorat Pendidikan Diniyah dan Pondok Pesantren harus membuat pedoman pengajaran kitab kuning umumnya, dan khususnya kitab-kitab fiqih, di pesantren. Bagi pesantren yang menyelenggarakan Pendidikan formal perlu diperkuat sistem boarding dan menambah alokasi waktu dalam bentuk "jam wajib belajar kitab kuning" Bagi pesantren yang tidak menyelenggarakan Pendidikan formal (pesantren salafiyah murni) ditambah jenis kitab yang diajarkan.

2. Pemerintah memiliki kewajiban mengayomi aspirasi Pendidikan di pesantren dengan memberikan kebebasan memilih antara mendapat pengakuan dari negara (pengakuan kesetaraan) dengan yang menginginkan menjadi ulama murni tanpa ada pengaturan dari luar pesantren.

3. Adanya pengulangan pengajaran kitab fiqih tertentu pada tingkat tertentu dengan tujuan pendalaman materi kitab fiqih perlu dikaji ulang dengan penuntasan pengajaran kitab fiqih pada satu tingkat tertentu.

4. Hasil survei ini dapat dijadikan data awal (base data) dalam pengambilan kebijakan Pemerintah, khususnya Kementerian Agama dalam menyusun kebijakan pengembangan Pendidikan pesantren, seperti penyusunan bahan instrumen penilaian khusus yang tercantum dalam PP 19 Tahun 2005 tentang SNP pasal 93 ayat (2) dalam rangka standarisasi kurikulum dan kompetensi lulusan santri pesantren salafiyah.

5. Sebaiknya ada satu kajian dilanjutkan untuk mengungkap kualitas (penguasaan) kitab kuning umumnya dan khususnya kitab-kitab fiqih di pesantren.

\section{SUMBER BACAAN}

Azra, Azyumardi. 2002. " Kitab Kuning: Tradisi dan Epistemologi Keilmuan Islam di Indonesia", Azyumardi AZra, Pendidikn Islam: Tradisi dan Modernisasi Menuju Milenium Baru", Jakarta, Logos.

Bafadal, Fadhal A.R. dan M. Syatibi. 2006. Pergeseran Literatur Pondok Pesantren Salafiyah di Indonesia, Departemen Agama Ri, Badan Litbang dan Diklat Puslitbang Lektur Keagamaan.

Bruinessen, Martin Van.1999. Kitab Kuning, Pesantren dan Tarekat: Tradisi-Tradisi Islam di Indonesia, Bandung, Mizan.

Dhofier, Zamakhsyari. 1982. Tradisi Pesantren: Studi tentang Pandangan Hidup Kyai, Jakarta, LP3ES.

EMIS, Statistik Pendidikan PD Ponten, Tahun ajaran 2009-2010.

Mastuhu.1994. Dinamika sistem Pendidikan Pesantren, INIS, Jakarta. 
Mas'udi, Masdar F. 1985. "Mengenal Pemikiran Kitab Kuning", M. Dawam Rahardjo (editor), Pergulatan Dunia Pesantren: Membangun Dari Bawah, Jakarta, P3M.

Mochtar, Affandi. 1999. "Tradisi Kitab Kuninng: Sebuah Observasi Umum," dalam Marzuki Wahid, dkk (penyunting), Pesantren Masa Depan: Wacana Pemberdayaan dan Transformasi Pesantren, Bandung, Pustaka Hidayah.
Steenbrink, Karel A. 1994. Pesantren, Madrasah, Sekolah: Pendidikan Islam dalam Kurun Moderen, Jakarta, LP3ES.

Surat edaran Direktorat Jenderal Kelembagaan Agama Islam, Nomor: Dj.II.II/V/PP.007/AZ/28/04 tanggal 9 Januari 2004

Wahid, Abdurahman. 2010. Menggerakkan Tradisi: Esai-Esai Pesantren, Yogyakarta, LkiS. 